\title{
PENGARUH BUDAYA, PERSEPSI, DAN KEPERCAYAAN TERHADAP KEPUTUSAN PEMBELIAN OBAT TRADISIONAL DI UKM PASAR KAHAYAN PALANGKA RAYA
}

\author{
Jaldi Hindratno ${ }^{1^{*}}$, Meitiana Sahay ${ }^{2 *}$, Yoga Manurung ${ }^{3^{*}}$ \\ 1,2,3 Fakultas Ekonomi dan Bisnis, Universitas Palangka Raya \\ *Corresponding : Jhidratno@gmail.com , metiana.sahay@gmail.com , yoga.manurung@feb.upr.ac.id
}

\begin{tabular}{|c|c|}
\hline CHRONICLE & ABSTRACT \\
\hline $\begin{array}{l}\text { Article History: } \\
\text { Received: October 1, } 2020 \\
\text { Revised: December 2020, } \\
\text { January } 2021 \\
\text { Accepted: Februari 6, } 2021 \\
\text { Keywords : } \\
\text { Culture, Perception, Trust, and } \\
\text { Purchasing Decisions }\end{array}$ & $\begin{array}{l}\text { This study aims to determine whether there is an influence of culture, } \\
\text { perceptions, and trust on purchasing decisions either partially or } \\
\text { simultaneously (jointly). The research method used in this research is a } \\
\text { descriptive-quantitative approach. The population in this study includes } \\
\text { all consumers or customers who have purchased traditional medicinal } \\
\text { products located on Jl.Tjilik Riwut KM.1, Kahayan Palangka Raya } \\
\text { market, whose numbers are not yet known. The sampling technique in } \\
\text { this study used a non-probability sampling technique with a type of } \\
\text { accidental sampling of } 80 \text { respondents. The data collection technique } \\
\text { used a questionnaire. The collected data were analyzed and processed } \\
\text { with the Statistical Package for the Social Sciences (SPSS) version } 24.0 \text {. } \\
\text { The results showed that there was a significant and positive influence of } \\
\text { culture, perceptions, and trust either partially or simultaneously on } \\
\text { purchasing decisions for traditional medicines in the UKM Kahayan } \\
\text { market, Palangka Raya. The suggestion given by the author in this study } \\
\text { is that shop owners are expected to continue working in processing } \\
\text { traditional medicine in order to increase the trust that traditional } \\
\text { medicine is proven to heal. The government should carry out scientific } \\
\text { testing to find out what content is in the drug, so that the BPOM and } \\
\text { MUI labels are immediately given so that it is known to the wider } \\
\text { community that these traditional medicines are suitable for } \\
\text { consumption. For further researchers, they should use or add other } \\
\text { variables such as social factors, psychological factors, and others so } \\
\text { that they can more influence the results of purchasing decisions. }\end{array}$ \\
\hline
\end{tabular}

\section{Latar Belakang :}

Usaha Kecil Menengah (UKM) di Indonesia memiliki potensi yang dapat dikembangkan dalam berbagai sektor dan strategi yang di dukung oleh berbagai macam pihak seperti pemerintah, swasta, ataupun pengusaha bidang industri kecil menengah lainnya. Indonesia merupakan negara kepulauan yang terletak di kawasan khatulistiwa dan dikenal sebagai salah satu negara dengan tingkat keanekaragaman yang tinggi. Kekayaan alam Indonesia, menyimpan berbagai tumbuhan yang berkhasiat obat dari 40 ribu jenis flora yang tumbuh di dunia, 30 ribu diantaranya tumbuh di Indonesia. Sebanyak 26\% yang telah dibudidayakan dan 74\% masih tumbuh liar di hutan, sebanyak 940 jenis tanaman telah digunakan sebagai obat tradisional.

Salah satu kajian menarik dalam pemasaran adalah perilaku konsumen, kajian perilaku konsumen juga dapat digunakan untuk melihat perilaku masyarakat terhadap penggunaan obat herbal $[1,2]$. Ditengah kemajuan teknologi, terdapat kecenderungan masyarakat untuk kembali pada alam (back to nature) sebagai titik awal berkembangnya obat herbal. Slogan back to nature menunjukkan tuntutan minimnya efek negatif yang ditimbulkan [3-5]. Obat herbal diposisikan sebagai antioksidan (menangkal radikal bebas), imunomodulator (meningkatkan sistem imun), dan degeneratif (mencegah penyakit). Hal ini terjadi akibat perubahan lingkungan, pola hidup manusia, dan perkembangan pola penyakit yang semakin meningkat.

Melonjaknya biaya pengobatan dengan taraf kemampuan ekonomi yang terbatas membuat obat herbal menjadi salah satu solusi baik untuk menanggulangi masalah tersebut [6,7]. Seiring dengan perubahan lingkungan bisnis dan akibat dari semakin meningkatnya wabah virus corona (Covid-19) di Indonesia, diketahui obat herbal seperti jamu atau empon-empon dikenal mampu meningkatan sistem imunitas atau daya tahan tubuh. Tentu hal ini membuat banyak masyarakat yang tergiur 
akan khasiat obat herbal dalam mencegah penularan virus corona. Tapi faktanya, tidak semua obat herbal dapat diklasifikasikan dalam kategori dapat memelihara daya tahan tubuh.

Virus corona (Covid-19) merupakan virus yang berbahaya lantaran dapat menyebar dengan cepat. Puluhan bahkan jutaan orang di seluruh dunia meninggal akibat virus ini. Untuk menghindari virus corona (covid-19), berbagai tindakan pencegahan telah dilakukan oleh masyarakat di Indonesia. Berbagai cara tradisional dipercaya dapat mengatasi berbagai masalah kesehatan [8-11]. Pengobatan herbal sering dinilai berhasil karena konsumen penggunanya memiliki keyakinan terhadap kesembuhan penyakitnya lewat pengobatan herbal. Konon katanya semakin kuat kepercayaannya maka semakin jelas kesembuhannya. Oleh karena itu, bagi konsumen yang tidak percaya terhadap khasiat pengobatan herbal, maka sulit mewujudkan kesembuhan penyakitnya lewat pengobatan herbal. Kurang percaya dapat dijadikan sebagai faktor kepercayaan. Selanjutnya faktor budaya, faktor persepsi, dan faktor kepercayaan merupakan bagian dari faktor karakteristik konsumen. Berdasarkan uraian diatas,maka penulis tertarik untuk melakukan penelitian mengenai budaya, persepsi, dan kepercayaan terhadap keputusan pembelian obat tradisional di UKM pasar kahayan Palangka Raya.

\section{Tinjauan Pustaka}

\section{$2.1 \quad$ Budaya}

Definisi budaya merupakan penyebab yang paling mendasar dari keinginan dan tingkah laku seseorang, tingkah laku seseorang itu dipelajari dan tumbuh dalam suatu masyarakat, sebagaimana seseorang mempelajari nilai-nilai dasar persepsi, keinginan, dan tingkah laku dari keluarga serta lembagalembaga penting di dalam masyarakat yang lain. Seseorang akan belajar atau berhadapan dengan nilai-nilai tentang bagaimana mencapai tujuan dengan sukses, aktif dan efisiensi di dalam mengejar kemajuan $[3,7]$. Sebagaimana seseorang akan mempelajari hal-hal tersebut, kenyamanan terhadap materi yang dimiliki, setiap kelompok atau masyarakat memberikan pengaruh paling luas pada perilaku konsumen. Di dalam kontek ini manajemen harus mengetahui peranan yang dimainkan oleh budaya, sub budaya dan kelas sosial pembeli. Sub budaya dapat dibedakan menjadi beberapa jenis seperti kelompok nasionalisme, kelompok keagamaan, kelompok ras, dan area geografi. Kelas-kelas sosial tersebut meliputi kelompok masyarakat yang relatif permanen dan bertahan lama sehingga tersusun dan keanggotaannya memiliki nilai, minat dan perilaku yang sama $[6,8]$.

Budaya merupakan sebuah determinan atas dasar keinginan dan perilaku seseorang, melalui keluarga dan institusi lainnya, dalam sebuah hubungan dengan orang lain. Seorang pemasar yang kritis di dalam ilmu manajemen harus memperhatikan nilai budaya pada setiap area pemasaran [9]. Untuk memahami cara-cara memasarkan produk dan jasa lama mereka dan mencari peluang bagi produk dan jasa baru, diharapkan dapat membentuk pengembangan melalui transmisi yang berawal dari kepercayaan manusia melalui simbol-simbol yang dapat diingat dengan mudah, misalnya simbol bahasa sebagai rangkaian simbol yang digunakan untuk mengalihkan keyakinan budaya diantara para anggota suatu masyarakat terhadap pesan-pesan tentang produk dan jasa yang dihasilkan oleh perusahaan.

Kebiasaan suatu masyarakat dalam menanggapi sesuatu yang dianggap memiliki nilai dan kebiasaan dikatakan sebagai faktor budaya. Faktor ini bisa dimulai dari mereka menerima informasi, posisi sosial mereka dalam masyarakat, dan pengetahuan mereka tentang apa yang mereka rasakan. Budaya merupakan penentu yang mendasar atas keinginan dan perilaku seseorang. Kemudian sebagian perulangan keseluruhan tindakan atau aktivitas manusia dan produk yang dihasilkan manusia yang telah memasyarakat secara sosial dan bukan sekedar dialihkan secara genetikal. Lebih lanjut budaya memiliki pengaruh yang luas dan mendalam terhadap perilaku konsumen dalam pembelian. Budaya memiliki peran budaya di dalam membentuk kumpulan nilai, persepsi, preferensi dan perilaku. Akan tetapi kelas sosial konsumen sangatlah penting untuk diketahui dari area pemasaran yang mencakup kepercayaan, adat istiadat, normanorma artistik, yang di peroleh bukan dari kreatifitasnya sendiri melainkan merupakan warisan masa lampau.

\section{$2.2 \quad$ Persepsi}

Istilah persepsi sering disebut juga disebut juga dengan pandangan, gambaran, atau anggapan, sebab dalam persepsi terdapat tanggapan seseorang mengenai satu hal atau objek [8-11]. Definisi persepsi merupakan suatu proses yang didahului oleh penginderaan yaitu merupakan proses yang berwujud diterimanya stimulus oleh individu melalui alat indera atau juga disebut proses sensoris. Persepsi adalah proses yang menyangkut masuknya pesan atau informasi kedalam otak manusia, melalui persepsi manusia terus menerus mengadakan hubungan dengan lingkungannya. Hubungan ini dilakukan lewat inderanya, yaitu indera pengelihat, pendengar, peraba, perasa, dan pencium.

Orang yang termotivasi siap bertindak. Bagaimana ia bertindak dipengaruhi oleh pandangannya tentang situasi. Dalam pemasaran, persepsi lebih penting daripada realitas, karena persepsi konsumen 
mempengaruhi perilaku aktual konsumen. Persepsi (perception) adalah proses dimana kita memilih, mengatur, dan menerjemahkan masukan informasi untuk menciptakan gambaran dunia yang berarti. Poin utamanya adalah bahwa persepsi tidak hanya tergantung pada rangsangan fisik, tetapi juga pada hubungan rangsangan terhadap bidang yang mengelilinginya dan kondisi dalam setiap diri kita. Dalam pemasaran persepsi lebih penting daripada realitas, karena persepsi yang mempengaruhi perilaku aktual konsumen. Orang bisa mempunya persepsi berbeda tentang obyek yang sama karena tiga proses pemahaman; atensi selektif, distori selektif, dan retensi selektif. Persepsi merupakan suatu proses yang timbul akibat adanya sensasi, dimana sensasi adalah aktivitas merasakan atau penyebab keadaan emosi yang cepat dari indra penerima kita terhadap stimuli dasar seperti cahaya, warna, dan suara. Dengan adanya itu semua, persepsi akan timbul. Persepsi dibentuk oleh:

1) Karakteristik dari stimuli

2) Hubungan stimuli dengan sekelilingnya

3) Kondisi-kondisi di dalam diri kita sendiri Stimuli adalah setiap bentuk fisik, visual atau komunikasi verbal yang dapat mempengaruhi tanggapan individu. Persepsi mempunyai sifat subjektif, karena bergantung pada kemampuan dan keadaan dari masing-masing individu, sehingga akan ditafsirkan berbeda oleh individu yang satu dengan yang lain. Dengan demikian persepsi merupakan proses perlakuan individu yaitu pemberian tanggapan, arti, gambaran, atau penginterprestasian terhadap apa yang dilihat, didengar, atau dirasakan oleh indranya dalam bentuk sikap, pendapat, dan tingkah laku atau disebut sebagai perilaku individu.

\subsection{Kepercayaan}

Kepercayaan adalah kesediaan perusahaan untuk bergantung pada mitra bisnis. Kepercayaan tergantung pada beberapa faktor antar pribadi dan antar organisasi seperti kompetensi, integritas, kejujuran dan kebaikan hati. Membangun kepercayaan bisa menjadi hal yang sulit dalam situasi online, perusahaan menerapkan peraturan ketat kepada mitra bisnis online mereka dibanding mitra lainnya [5]. Pembeli bisnis khawatir bahwa mereka tidak akan mendapatkan produk atau jasa dengan kualitas yang tepat dan dihantarkan ke tempat yang tepat pada waktu yang tepat, begitupun sebaliknya. Kepercayaan konsumen mengandung arti bahwa semua pengetahuan yang dimiliki oleh konsumen dan semua kesimpulan yang dibuat oleh konsumen mengenai objek, atribut dan manfaatnya [9,12].

Kepercayaan merupakan sebuah keyakinan dari salah satu pihak mengenai maksud dan perilaku yang ditujukan kepada pihak yang lainnya, dengan demikian kepercayaan konsumen didefinisikan sebagai suatu harapan konsumen bahwa penyedia jasa dan produk bisa dipercaya atau diandalkan dalam memenuhi janjinya [13]. Kepercayaan didefinisikan sebagai bentuk sikap yang menunjukkan perasaan suka dan tetap bertahan untuk menggunakan suatu produk atau merek. Kepercayaan akan timbul dari benak konsumen apabila produk yang dibeli mampu memberikan manfaat atau nilai yang diinginkan konsumen pada suatu produk.

Kepercayaan sebagai suatu kondisi ketika salah satu pihak yang terlibat dalam proses pertukaran yakin dengan keandalan dan integritas pihak lain [12,14]. Definisi tersebut menjelaskan bahwa kepercayaan adalah kesediaan atau kerelaan untuk bersandar pada rekan yang terlibat dalam pertukaran yang diyakini. Kerelaan merupakan hasil dari sebuah keyakinan bahwa pihak yang terlibat dalam pertukaran akan memberikan kualitas yang konsisten, kejujuran, bertanggung jawab, ringan tangan dan berhati baik. Keyakinan ini akan menciptakan sebuah hubungan yang dekat antar pihak yang terlibat pertukaran.

\subsection{Keputusan Pembelian}

Keputusan pembelian merupakan serangkaian proses yang berawal dari konsumen mengenal masalahnya, mencari informasi tentang produk atau merek tertentu dan mengevaluasi produk atau merek tersebut seberapa baik masing-masing alternatif tersebut dapat memecahkan masalahnya, yang kemudian serangkaian proses tersebut mengarah kepada keputusan pembelian [14-16]. Keputusan pembelian adalah Suatu keputusan konsumen yang dipengaruhi oleh ekonomi keuangan, teknologi, politik, budaya, produk, harga, lokasi, promosi, physical evidence, people dan process, sehingga membentuk suatu sikap pada konsumen untuk mengolah segala informasi dan mengambil kesimpulan berupa response yang muncul produk apa yang akan dibeli [17]. Tipe-tipe keputusan pembelian tersebut dapat dikelompokan kedalam empat tipe, dalam keputusan pembelian, yaitu: 
Tabel 2.1 Tipe-tipe Keputusan Pembelian [6,9]

\begin{tabular}{|l|l|l|}
\hline & High Involvement & Low Involvement \\
\hline $\begin{array}{l}\text { Significant Differences } \\
\text { Between Brands }\end{array}$ & Complex Buying Behavior & $\begin{array}{l}\text { Variety-Seeking Buying } \\
\text { behavior }\end{array}$ \\
\hline $\begin{array}{l}\text { Few Differences Between } \\
\text { Brands }\end{array}$ & $\begin{array}{l}\text { DissonanceReducing } \\
\text { Buying Behavior }\end{array}$ & $\begin{array}{l}\text { Habitual Buying } \\
\text { Behavior }\end{array}$ \\
\hline
\end{tabular}

Sumber : penulis [5,9]

Proses keputusan pembelian adalah proses lima tahap yang dilewati konsumen, dimulai dari pengenalan masalah, pencarian informasi, evaluasi alternatif yang dapat memecahkan masalahnya, keputusan pembelian, dan perilaku pasca pembelian, yang dimulai jauh sebelum pembelian yang sesungguhnya dilakukan oleh konsumen dan memiliki dampak yang lama setelah itu. Berdasarkan kajian literatur dan teori, maka dibangunlah kerangka penelitian berikut.

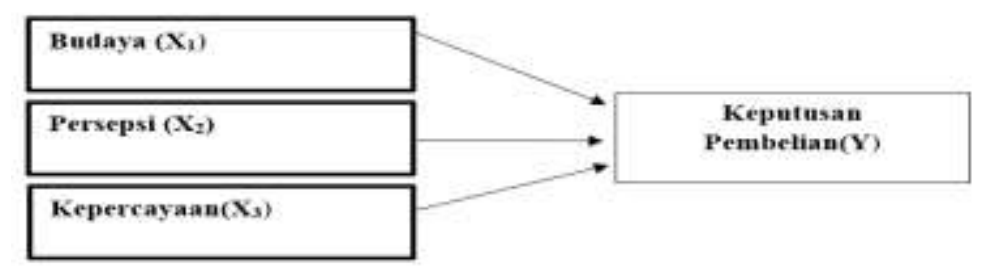

Gambar 1. Kerangka Penelitian (sumber : penulis)

\section{Metode Penelitian}

Jenis penelitian yang dilakukan dalam penelitian ini adalah kuantitatif eksploratif. Penelitian eksploratif yaitu suatu penelitian yang dilakukan ketika tidak banyak yang diketahui mengenai situasi yang akan terjadi, atau tidak ada informasi yang tersedia mengenai bagaimana masalah atau persoalan penelitian yang hampir sama diselesaikan dimasa lalu. Studi eksploratif diperlukan ketika sejumlah fakta diketahui, tetapi diperlukan lebih banyak informasi untuk menyusun kerangka teoritis yang kuat [10,14-17]. Teknik pengambilan sampel dalam penelitian ini menggunakan teknik non- probability sampling dengan jenis accidental sampling. Accidental sampling adalah teknik penentuan sampel berdasarkan kebetulan, yaitu konsumen yang secara kebetulan/insidental bertemu dengan peneliti yang dapat digunakan sebagai sampel, bila dipandang orang yang kebetulan ditemui itu cocok sebagai sumber data.

Adapaun metode yang digunakan dalam penelitian ini menggunakan metode analisis regresi linear berganda,Analisis linear berganda adalah hubungan secara linear anatara dua atau lebih variabel independen $(\mathrm{X} 1, \mathrm{X} 2, \mathrm{X} 3 \ldots \mathrm{Xn})$ dengan variabel dependen $(\mathrm{Y})$. Digunakan metode analisis regresi linear berganda agar hasil yang diperoleh lebih terarah. Adapun bentuk model analisis berganda tersebut adalah sebagai berikut:

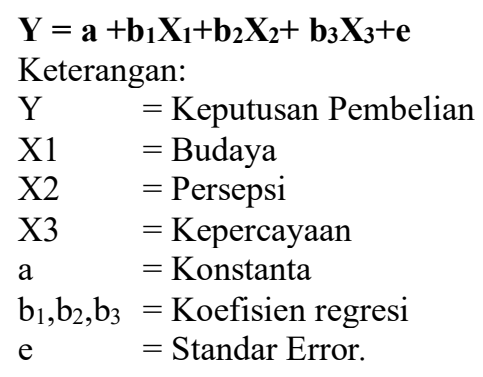

Adapun langkah- langkah dalam pengujiannya adalah sebagai berikut:

1. Merumuskan Hipotesis

a. $\quad H_{0}:$ bi $=0$, artinya variabel independen tidak memliki pengaruh yang signifikan terhadap variabel dependen.

b. $H_{a}$ : bi $\neq 0$, artinya variabel independen memliki pengaruh yang signifikan terhadap variabel dependen.

2. Menghitung nilai $t_{\text {hitung }}$ dengan cara $t_{\text {hitung }}=\frac{\mathrm{b} i}{s_{\mathrm{b} i}}$ atau lihat hasil SPSS. 
Dimana:

bi $\quad=$ Koefisien regresi

Sbi $\quad=$ Kesalahan standar dari koefisien regresi

3. Setelah mengikuti kriteria pengujian pengambilan keputusan, maka untuk pengambilan keputusan yaitu: $\alpha=0,05$

a. Jika nilai $t_{\text {hitung, }} \geq t_{\text {tabel, }}$, atau signifikansi $\leq 0,05$ maka Ho ditolak dan Ha diterima yang berarti dapat disimpulkan bahwa variabel-variabel independen terbukti secara statisitik berpengaruh signifikan secara parsial terhadap variabel dependen.

b. Jika nilai $t_{\text {hitung, }}<t_{\text {tabel, }}$, atau signifikansi $>0,05$ maka Ho diterima dan Ha ditolak yang berarti dapat disimpulkan bahwa variabel- variabel independen terbukti secara statisitik tidak berpengaruh signifikan secara parsial terhadap variabel dependen.

\section{Hasil Penelitian}

Penelitian ini menggunakan analisis linier berganda dalam uji $\mathrm{F}$ yang digunakan untuk menentukan apakah secara bersama-sama variabel independen mampu menjelaskan variabel dependen dengan baik atau apakah variabel independen mempunyai pengaruh yang signifikan terhadap variabel dependen secara bersama-sama. Dikemukakan rumus yang digunakan untuk menguji hipotesis tersebut yaitu:

$$
\mathrm{F}=\frac{r^{2} /(\mathrm{k}-1)}{\left.1-r^{2}\right) / N-k}
$$

Dimana:

$\mathrm{r}^{2} \quad=$ Koefisien determinasi

$\mathrm{N} \quad=$ Banyaknya sampel (observasi)

$\mathrm{k}=$ Banyaknya parameter/koefisien regresi plus konstanta

Kriteria Pengujian :

a. Apabila nilai $\mathrm{F}$ hitung $<\mathrm{F}$ tabel, maka Ho diterima. Artinya semua koefisien regresi secara bersamasama tidak signifikan pada taraf signifikansi $5 \%$

b. Apabila nilai $\mathrm{F}$ hitung $>\mathrm{F}$ tabel, maka Ho ditolak. Artinya semua koefisien regresi secara bersamasama signifikan pada taraf signifikansi $5 \%$.

Selanjutnya pengujian koefisien determinasi $\left(R^{2}\right)$ pada intinya mengukur seberapa jauh kemampuan model dalam menentukan variasi variabel dependen. Nilai koefisien determinasi $\left(R^{2}\right)$ yang mendekati satu, berarti variabel- variabel independennya menjelaskan hampir semua informasi yang dibutuhkan untuk memprediksi variabel dependen.

Kelemahan mendasar penggunaan koefisien determinasi adalah biasa terhadap jumlah variabel independen yang dimasukkan ke dalam model. Setiap tambahan satu variabel independen maka $\left(R^{2}\right)$ pasti meningkat tidak peduli apakah variabel tersebut berpengaruh secara signifikan terhadap variabel dependen. Oleh sebab itu, banyak peneliti menganjurkan untuk menggunakan nilai Adjusted $\mathrm{R}^{2}$ pada saat mengevaluasi yang mana model regresi terbaik. Tidak seperti $\mathrm{R}^{2}$, nilai Adjusted $\mathrm{R}^{2}$ dapat naik turun apabila satu variabel independen ditambahkan kedalam model.

\subsection{Hasil Uji Regresi}

Analisis regresi linear berganda digunakan untuk meguji hubungan secara linear antara dua atau lebih variabel independen. Berdasarkan hasil dari analisis data dengan menggunakan program komputer yaitu SPSS versi 24 , diperoleh perhitungan regresi linear berganda antara variabel budaya $\left(\mathrm{X}_{1}\right)$, persepsi $\left(\mathrm{X}_{2}\right)$, dan kepercayaan $\left(\mathrm{X}_{3}\right)$ terhadap variabel keputusan pembelian $(\mathrm{Y})$ yaitu: 


\section{.}

,

Tabel 4.1. Analisis Regresi Linear Berganda

\begin{tabular}{|c|c|c|c|c|c|c|}
\hline \multicolumn{7}{|c|}{ Coefficients $^{\mathrm{a}}$} \\
\hline \multirow{2}{*}{\multicolumn{2}{|c|}{ Model }} & \multicolumn{2}{|c|}{$\begin{array}{l}\text { Unstandardized } \\
\text { Coefficients }\end{array}$} & \multirow{2}{*}{$\begin{array}{c}\begin{array}{c}\text { Standardized } \\
\text { Coefficients }\end{array} \\
\text { Beta }\end{array}$} & \multirow[t]{2}{*}{$\mathrm{t}$} & \multirow[t]{2}{*}{ Sig. } \\
\hline & & $\mathrm{B}$ & Std. Error & & & \\
\hline \multirow[t]{4}{*}{1} & (Constant) & ,718 & ,215 & & 3,334 & ,001 \\
\hline & BUDAYA & ,344 & 062 & ,454 & 5,532 &, 000 \\
\hline & PERSEPSI & ,226 &, 059 & 271 & 3,850 &, 000 \\
\hline & KEPERCAYAAN &, 245 &, 067 & ,284 & 3,666 &, 000 \\
\hline
\end{tabular}

Berdasarkan Tabel 4.11 diatas, maka dapat diperoleh persamaan regresi sebagai berikut:

$\mathrm{Y}=0,718+0,344 \mathrm{X}_{1}+0,226 \mathrm{X}_{2}+0,245 \mathrm{X}_{3}$

Dimana:

$\mathrm{Y} \quad=$ Keputusan pembelian

$\mathrm{X} 1=$ Budaya

$\mathrm{X} 2=$ Persepsi

$\mathrm{X} 3=$ Kepercayaan.

Dimana:

1. Nilai 0,718 adalah nilai konstanta yang bernilai positif artinya ketika variabel budaya, persepsi, dan kepercayaan dianggap konstan (tetap) atau tidak ada perubahan, maka besar keputusan pembelian sebesar 0,718 .

2. Besar pengaruh variabel budaya $\left(\mathrm{X}_{1}\right)$ menunjukan nilai positif sebesar 0,344 . Artinya jika budaya meningkat 1 satuan maka nilai budaya akan meningkat sebesar 0,344 sehingga semakin baik penilaian konsumen terhadap budaya maka semakin meningkat pula keputusan pembelian.

3. Besar pengaruh variabel persepsi $\left(\mathrm{X}_{2}\right)$ menunjukan nilai positif sebesar 0,226 . Artinya jika persepsi meningkat 1 satuan maka nilai persepsi akan meningkat sebesar 0,226 sehingga semakin baik penilaian konsumen terhadap persepsi maka semakin meningkat pula keputusan pembelian.

4. Besar pengaruh variabel kepercayaan $\left(\mathrm{X}_{3}\right)$ menunjukan nilai positif sebesar 0,245 . Artinya jika persepsi meningkat 1 satuan maka nilai persepsi akan meningkat sebesar 0,245 sehingga semakin baik penilaian konsumen terhadap kepercayaan maka semakin meningkat pula keputusan pembelian.

\subsection{Uji Hipotesis}

Uji hipotesis yang dilakukan dalam penelitian ini bertujuan untuk mengetahui apakah ada pengaruh dari variabel independen terhadap variabel dependen. Uji hipotesis terdiri dari uji t (uji parsial) dan uji F (uji simultan).

\subsubsection{Hasil Uji t}

Uji t digunakan untuk menunjukan signifikansi pengaruh variabel budaya $\left(\mathrm{X}_{1}\right)$, persepsi $\left(\mathrm{X}_{2}\right)$, dan variabel kepercayaan $\left(\mathrm{X}_{3}\right)$ terhadap variabel keputusan pembelian $(\mathrm{Y})$ secara parsial atau masing-masing dengan diperoleh $\mathrm{t}_{\text {tabel }}=1,665$ (ttabel pada $\mathrm{df}=76$ dengan uji dua sisi). Berdasarkan Tabel 4.3 dapat dilihat bahwa:

1. Pengaruh Variabel budaya terhadap keputusan pembelian $(\mathrm{Y})$ menunjukan nilai $\mathrm{t}_{\text {hitung }}=5,532>\mathrm{t}_{\text {tabel }}=$ 1,665 atau nilai signifikansi $0,000<0,05$. Maka Ho ditolak dan Ha diterima, artinya variabel budaya $\left(\mathrm{X}_{1}\right)$ secara parsial berpengaruh signifikan terhadap variabel keputusan pembelian $(\mathrm{Y})$.

2. Pengaruh Variabel persepsi terhadap keputusan pembelian $(\mathrm{Y})$ menunjukan nilai $\mathrm{t}_{\text {hitung }}=3,850>\mathrm{t}_{\text {tabel }}$ $=1,665$ atau nilai signifikansi $0,000<0,05$. Maka Ho ditolak dan Ha diterima, artinya variabel persepsi $\left(\mathrm{X}_{2}\right)$ secara parsial berpengaruh signifikan terhadap variabel keputusan pembelian $(\mathrm{Y})$.

3. Pengaruh Variabel kepercayaan terhadap keputusan pembelian $(\mathrm{Y})$ menunjukan nilai $\mathrm{t}_{\text {hitung }}=3,666>$ $\mathrm{t}_{\text {tabel }}=1,665$ atau nilai signifikansi $0,000<0,05$. Maka Ho ditolak dan Ha diterima, artinya variabel kepercayaan $\left(\mathrm{X}_{3}\right)$ secara parsial berpengaruh signifikan terhadap variabel keputusan pembelian $(\mathrm{Y})$.

\subsubsection{Hasil Uji F}

Uji F digunakan untuk mengetahui apakah variabel budaya (X1), persepsi (X2), dan kepercayaan (X3) secara simultan atau bersama-sama berpengaruh terhadap variabel keputusan pembelian (Y). Berdasarkan hasil uji pada Tabel 4.12 untuk mengetahui tingkat signifikansi secara simultan atau bersamasama, variabel terdiri dari variabel budaya, persepsi, dan kepercayaan terhadap variabel keputusan 
pembelian pada penggunaan regresi linear berganda, maka digunakan uji F yang dapat dibuktikan sebagai berikut:

Tabel 4.2. Hasil uji F

\begin{tabular}{|c|c|c|c|c|c|c|}
\hline \multicolumn{7}{|c|}{ ANOVA $^{\mathbf{a}}$} \\
\hline \multicolumn{2}{|c|}{ Model } & $\begin{array}{c}\text { Sum of } \\
\text { Squares }\end{array}$ & $\mathrm{df}$ & Mean Square & $\mathrm{F}$ & Sig. \\
\hline \multirow[t]{3}{*}{1} & Regression & 6,646 & 3 & 2,215 & 87,266 &, $000^{\mathrm{b}}$ \\
\hline & Residual & 1,929 & 76 & 025 & & \\
\hline & Total & 8,575 & 79 & & & \\
\hline \multicolumn{7}{|c|}{ a. Dependent Variable: KEPUTUSAN PEMBELIAN } \\
\hline \multicolumn{7}{|c|}{ b. Predictors: (Constant), KEPERCAYAAN, PERSEPSI, BUDAYA } \\
\hline
\end{tabular}

Berdasarkan Tabel 4.12 diatas diperoleh hasil sebagai berikut:

1. $F_{\text {hitung }}=87,266$

2. $\mathrm{F}_{\text {tabel }}$ yang diperoleh berdasarkan $\mathrm{df} 1=(\mathrm{k}-1)$ sehingga df $1=(4-1)=3$, df $2=(\mathrm{n}-\mathrm{k})$ sehingga df $2=(80-$

4) $=76$ dengan taraf signifikan 0,05 , sehingga diperoleh $F_{\text {tabel }}=3,12$. Hal ini menyatakan bahwa $F_{\text {hitung }}$ $=87,266>\mathrm{F}_{\text {tabel }} 3,12$ atau nilai signifikansi $0,000<0,05$. Maka Ho ditolak dan Ha diterima, artinya variabel budaya $\left(\mathrm{X}_{1}\right)$, persepsi $\left(\mathrm{X}_{2}\right)$, dan kepercayaan $\left(\mathrm{X}_{3}\right)$ secara simultan atau bersama-sama berpengaruh terhadap variabel keputusan pembelian (Y).

\subsubsection{Koefisien Determinasi $\left(\mathrm{R}^{2}\right)$}

Koefisien Determinasi $\left(\mathrm{R}^{2}\right)$ digunakan untuk mengetahui seberapa jauh kemampuan variabel independen yaitu variabel budaya $\left(\mathrm{X}_{1}\right)$, persepsi $\left(\mathrm{X}_{2}\right)$, dan kepercayaan $\left(\mathrm{X}_{3}\right)$ dalam menerangkan variasi variabel dependen yaitu keputusan pembelian (Y).

Tabel 4.3. Koefisien Determinasi $\left(\mathbf{R}^{2}\right)$

\begin{tabular}{|l|c|c|c|c|c|}
\hline \multicolumn{7}{|l|}{ Model Summary $^{\mathbf{b}}$} \\
\hline 1 & $\mathrm{R}$ & R Square & $\begin{array}{c}\text { Adjusted R } \\
\text { Square }\end{array}$ & $\begin{array}{c}\text { Std. Error Of } \\
\text { The Estimate }\end{array}$ & Durbin-Watson \\
\hline \multicolumn{7}{|l}{ a. Predictors: (Constant), Kepercayaan, Persepsi, Budaya } \\
\hline
\end{tabular}

Berdasarkan Tabel 4.13 diketahui bahwa dari hasil perhitungan diperoleh nilai Koefisien Determinasi Adjusted R Square sebesar 0,766 atau 76,6\%. Hal ini menunjukan bahwa 76,6\% variabel keputusan pembelian dapat dijelaskan oleh variabel budaya, persepsi, dan kepercayaan. Sedangkan sisanya 23,4\% variabel keputusan pembelian dipengaruhi variabel-variabel lainnya yang tidak diteliti dalam penelitian ini.

\section{Kesimpulan}

Berdasarkan hasil dari analisis menunjukan bahwa indikator-indikator variabel budaya (biasa menggunakan, biasa memperoleh manfaatnya, biasa menyarankan) memiliki pengaruh terhadap keputusan pembelian. Item pernyataan ke-3 memiliki rata-rata tertinggi sebesar 4,35. Hal ini menunjukan bahwa konsumen sudah sering memakai produk obat tradisional karena khasiatnya yang alami. Sedangkan produk obat tradisional berdasarkan khasiatnya disarankan kepada keluarga dan teman-teman untuk membelinya. Berdasarkan hasil analisis regresi linear berganda dapat dilihat bahwa variabel budaya berpengaruh positif terhadap keputusan pembelian dengan nilai estimasi 0,344. Artinya jika penilaian konsumen pada budaya naik 1 satuan, maka keputusan pembelian konsumen akan mengalami kenaikan sebesar 0,344. Sehingga semakin baik penilaian konsumen terhadap budaya obat tradisional, maka semkin meningkat pula keputusan pembelian konsumen yang memiliki indikator pilihan produk, pilihan merek, pilihan penyalur dan waktu pembelian. Berdasarkan hasil analisis regresi linear berganda dapat dilihat bahwa variabel persepsi berpengaruh positif dan signifikan terhadap keputusan pembelian dengan nilai estimasi 0,226. Artinya jika penilaian konsumen pada persepsi naik 1 satuan, maka keputusan pembelian konsumen akan mengalami kenaikan sebesar 0,226. Sehingga semakin baik penilaian konsumen terhadap persepsi obat tradisional, maka semakin meningkat pula keputusan pembelian konsumen. Dari hasil uji t dalam penelitian ini dapat diketahui bahwa variabel persepsi yang memiliki indikator terjamin, cepat sembuh, 
berkhasiat, terbukti, efek samping rendah, harganya murah berpengaruh secara parsial terhadap keputusan pembelian obat tradisional di kota Palangka Raya.

Berdasarkan hasil dari analisis menunjukan bahwa indikator-indikator variabel kepercayaan (percaya khasiatnya, percaya kandungannya, percaya manfaatnya), memiliki pengaruh terhadap keputusan pembelian. Hal ini menunjukan bahwa produk obat tradisional dipercayai memiliki khasiat yang dapat menyembuhkan penyakit dan bahwa produk obat tradisional memiliki manfaat sebagai obat alternatif untuk membantu masyarakat dalam menyembuhkan penyakit. Selanjutnya, berdasarkan hasil analisis regresi linear berganda dapat dilihat bahwa variabel budaya berpengaruh positif terhadap keputusan pembelian dengan nilai estimasi 0,245. Artinya jika penilaian konsumen pada kepercayaan naik 1 satuan, maka keputusan pembelian konsumen akan mengalami kenaikan sebesar 0,245. Sehingga semakin baik penilaian konsumen terhadap kepercayaan obat tradisional, maka semakin meningkat pula keputusan pembelian konsumen. Dari hasil uji t dalam penelitian ini dapat diketahui bahwa variabel kepercayaan berpengaruh secara parsial terhadap keputusan pembelian obat tradisional di kota Palangka Raya, hasil penelitian ini sangat baik untuk meningkatkan keputusan pembelian. Selanjutnya untuk penelitian selanjutnya dapat di jadikan literatur pentingnya atribut produk untuk meningkatkan kepercayaan konsumen dapat meningkatkan kinerja pemasaran. Hal ini sangat berperan bukan hanya dalam meningkatkan keputusan pembelian produk.

\section{REFERENSI}

[1] Adyanto, B. C., \& Santosa, S. B. (2018). Pengaruh Kualitas Layanan, Brand Image, Harga Dan Kepercayaan Produk Terhadap Keputusan Pembelian (Studi Layanan E-Commerce Berrybenka. com). Diponegoro Journal of Management, 7(1), 10-29.

[2] Nasution, S. L. A., Limbong, C. H., \& Ramadhan, D. A. (2020). Pengaruh Kualitas Produk, Citra Merek, Kepercayaan, Kemudahan, Dan Harga Terhadap Keputusan Pembelian Pada E-Commerce Shopee (Survei pada Mahasiswa S1 Fakultas Ekonomi Jurusan Manajemen Universitas Labuhan Batu). Ecobisma (Jurnal Ekonomi, Bisnis Dan Manajemen), 7(1), 43-53.

[3] Rosdiana, R., \& Haris, I. A. (2018). Pengaruh Kepercayaan Konsumen Terhadap Minat Beli Produk Pakaian Secara Online. International Journal of Social Science and Business, 2(3), 169-175.

[4] Kristinae, V., Wardana, I., Giantari, I., \& Rahyuda, A. (2020). The role of powerful business strategy on value innovation capabilities to improve marketing performance during the COVID-19 pandemic. Uncertain Supply Chain Management, 8(4), 675-684.

[5] Sari, M. P., \& Sanjaya, V. F. (2021). Pengaruh Harga, Promosi, dan Kepercayaan Terhadap Keputusan Pembelian Produk YOU. Jurnal Manajemen dan Bisnis (JMB), 2(1).

[6] Maura Bella Assyifa, N., \& Setyawan, A. A. (2020). Kepercayaan Konsumen Terhadap Atribut Kepercayaan: Peran Kepercayaan Merek Pada Produk Minuman (Doctoral dissertation, Universitas Muhammadiyah Surakarta).

[7] Keren, K., \& Sulistiono, S. (2019). Pengaruh Motivasi, Budaya, dan Sikap Konsumen Terhadap Keputusan Pembelian Produk Indomie. Jurnal Ilmiah Manajemen Kesatuan, 7(3), 319-324.

[8] Anshory, B. J. (2017). Fenomena budaya konsumerisme praktis dalam perspektf desain produk.furniture. Jurnal Dimensi Seni Rupa dan Desain, 13(2), 131-140.

[9] Alim, S. A., Mawardi, M. K., \& Bafadhal, A. S. (2018). Pengaruh Persepsi Label Halal dan Kualitas Produk Terhadap Keputusan Pembelian Produk Fesyen Muslim (Survei pada Pelanggan Produk Zoya Muslim di Kota Malang). Jurnal Administrasi Bisnis, 62(1), 127-134.

[10] Rivai, A. R., \& Wahyudi, T. A. (2017). Pengaruh persepsi kualitas, citra merek, persepsi harga terhadap loyalitas pelanggan dengan kepercayaan dan kepuasan pelanggan sebagai variabel mediasi. Jurnal Bisnis Dan Komunikasi, 4(1), 29-37.

[11] Sumiati, S., \& Gea, D. (2021). Pengaruh Harga, Brand Image dan Kualitas Produk Terhadap Keputusan Pembelian Produk Obat Bermerek Pada PT. Bernofarm. Jurnal Manajemen Universitas Bung Hatta, 16(1), 57-67.

[12] Adi, P. H., \& Wicaksono, S. (2019). Faktor Yang Berpengaruh Terhadap Keputusan Pembelian Obat Di Apotek. Sustainable Competitive Advantage (SCA), 9(1).

[13] Christa, U. R., Wardana, I., Dwiatmadja, C., \& Kristinae, V. (2020). The Role of Value Innovation Capabilities in the Influence of Market Orientation and Social Capital to Improving the Performance of Central Kalimantan Bank in Indonesia. Journal of Open Innovation: Technology, Market, and Complexity, 6(4), 140.

[14] Widyaningrum, P. W. (2017). Pengaruh Label Halal dan Celebrity Endorser terhadap Keputusan Pembelian (Survei pada Konsumen Wardah di Ponorogo). JESI (Jurnal Ekonomi Syariah Indonesia), 6(2), 83-98. 
[15] Putranto, A. T., \& Rusmiati, H. (2018). Pengaruh Penetapan Harga Terhadap Keputusan Pembelian Pada Toko Grosir Herbal Di Pondok Aren, Tangerang Selatan. Jurnal Pemasaran Kompetitif, 3(1), 35-44.

[16] Marwati, M., \& Amidi, A. (2019). Pengaruh Budaya, Persepsi, Dan Kepercayaan Terhadap Keputusan Pembelian Obat Herbal. Jurnal Ilmu Manajemen, 7(2), 168-180.

[17] Wulandari, N. L. A. A. (2019). Analisis Faktor-Faktor Yang Mempengaruhi Keputusan Pembelian Produk Herbal Ayurveda (Studi Pada Konsumen di Kota Denpasar). Widya Kesehatan, 1(2), 28-38 